\title{
Calcium particle film improves sweet potato growth and partitioning ${ }^{1}$
}

\author{
Alexandre Passos Oliveira², Abraão Almeida Santos ${ }^{3}$, Pryanka Thuyra Nascimento Fontes², \\ Marcelo Augusto Gutierrez Carnelossi², Jailson Lara Fagundes ${ }^{2}$, Luiz Fernando Ganassali de Oliveira Junior ${ }^{2}$
}

\section{ABSTRACT}

High temperatures may affect the development and yield of the sweet potato crop. Technologies such as particle films can mitigate their effects. This study aimed to evaluate the effect of calcium oxide $(\mathrm{CaO})$ particle film on sweet potato remobilization and accumulation of photoassimilates, as well as its impact on the crop yield. The experimental design was randomized blocks, with four replicates per treatment: control, 5, 10 and $15 \%$ of CaO. In general, there was an increase for root volume; average weight per root; dry and fresh weight of roots, branches and leaves; and growth rates at $10 \%$ of $\mathrm{CaO}$. The highest yield and number of marketable roots were observed at 10 and $15 \%$ of $\mathrm{CaO}$. The use of $10 \%$ of $\mathrm{CaO}$ caused an increase in the remobilization of photoassimilates and, consequently, an increase in the sweet potato yield.

KEYWORDS: Ipomoea batatas L., calcium oxide, artificial shading, photoassimilates distribution.

\section{INTRODUCTION}

Sweet potato (Ipomoea batatas L.) is cultivated worldwide for human and animal feeding (Chandrasekara \& Kumar 2016). Around 107 million tons are produced annually, making it one of the most cultivated tuberous roots (FAO 2017). In Brazil, it is the fourth most consumed tuberous root, with an annual production estimated at 600,000 tons (IBGE 2017). The Northeast region is the primary producer of sweet potato in Brazil, mainly by small farmers, as it requires less technology and has a low production cost (Figueiredo et al. 2012).

Dry and warm conditions seem to limit the cultivation of sweet potato in the Brazilian Northeast

\begin{abstract}
RESUMO
Filme de partículas de cálcio

melhora o crescimento e partição de batata-doce

Altas temperaturas podem afetar o desenvolvimento e rendimento da cultura da batata-doce. Tecnologias como filmes de partículas podem mitigar seus efeitos. Objetivou-se avaliar o efeito de filme de partículas de óxido de cálcio $(\mathrm{CaO})$ na remobilização e acúmulo de fotoassimilados em batata-doce, bem como seu impacto na produtividade da cultura. $\mathrm{O}$ delineamento experimental foi em blocos ao acaso, com quatro repetições por tratamento: controle; 5; 10; e $15 \%$ de CaO. De maneira geral, houve aumento de volume radicular; peso médio por raiz; massa seca e fresca de raízes, ramos e folhas; e taxas de crescimento para $10 \%$ de $\mathrm{CaO}$. A maior produtividade e número de raízes comercializáveis foram observados para 10 e $15 \%$ de $\mathrm{CaO}$. A utilização de $10 \%$ de $\mathrm{CaO}$ causou aumento na remobilização de fotoassimilados e, consequentemente, aumento na produtividade da batata-doce.
\end{abstract}

PALAVRAS-CHAVE: Ipomoea batatas L., óxido de cálcio, sombreamento artificial, distribuição de fotoassimilados.

region due to water, thermal and luminous stress. The use of particle films is a promising technique that can improve the water consumption and increase the crop yield (Silva et al. 2019a), as observed for olive tree (Olea europaea) (Brito et al. 2018) and tomato (Solanum lycopersicum) (Silva et al. 2019b). Thus, particle films can mitigate unfavorable climate conditions on sweet potato crops in this region.

Quantitative analysis of plant growth consists of measuring the accumulation of dry mass and the size of the photosynthetic apparatus in regular intervals of time (Peixoto et al. 2011). For instance, there is a linear relationship between radiation intercepted by plants and dry matter production (Portes \& Melo 2014). Thus, partition and remobilization

${ }^{1}$ Received: Feb. 22, 2021. Accepted: July 20, 2021. Published: Aug. 19, 2021. DOI: 10.1590/1983-40632021v5167814.

${ }^{2}$ Universidade Federal de Sergipe, Departamento de Agronomia, São Cristóvão, SE, Brasil.

E-mail/ORCID: tande1992@gmail.com/0000-0002-1628-2597; pryankafontes@yahoo.com.br/0000-0002-1732-2503; carnelossi@ufs.br/0000-0002-2961-5557; ratinhojlf@yahoo.com.br/0000-0002-5583-6767; lfg.ufs@gmail.com/0000-0002-1589-0742.

${ }^{3}$ Universidade Federal de Viçosa, Departamento de Agronomia, Viçosa, MG, Brasil.

E-mail/ORCID: abraaoufs@gmail.com/0000-0001-5284-3294. 
are determining factors for plant yield (Gifford et al.1984). Changes in the distribution patterns of assimilates of the plant components by management practices, such as particle films, may help to increase the crop yield (Fahad et al. 2017). Thus, this study aimed to investigate if applying calcium oxide $(\mathrm{CaO})$ particle film can remobilize the photoassimilates of sweet potato plants and increase their yield.

\section{MATERIAL AND METHODS}

The experiment was performed in São Cristovão, Sergipe state, Brazil (10 $55^{\circ} 27^{\prime}$ 'S, $37^{\circ} 12^{\prime} 01^{\prime \prime} \mathrm{W}$ and $46 \mathrm{~m}$ of altitude), from April to September 2018. The climate is tropical rainy, with an average annual temperature of around $25.2{ }^{\circ} \mathrm{C}$, dry summer and average yearly rainfall of 1,300 mm, concentrated in April-September (Santos et al. 2009). During the experimental period, the weather conditions were monitored by a meteorological station installed in the experimental area (Figure 1).

The Ourinho variety, collected from the Itabaiana farm (Sergipe state), was used. Each branch contained 4-8 knots, and $50 \%$ were buried to implant the crop. Using the Penman-Monteith method, drip irrigation was used based on the evapotranspiration values (Allen et al. 1998). Fertilizers were applied at planting $\left(20 \mathrm{~kg} \mathrm{ha}^{-1}\right.$ of N, $90 \mathrm{~kg} \mathrm{ha}^{-1}$ of $\mathrm{P}_{2} \mathrm{O}_{5}$ and $90 \mathrm{~kg} \mathrm{ha}^{-1}$ of $\mathrm{K}_{2} \mathrm{O}$ ) and 30 days after planting (DAP) (30 kg ha ${ }^{-1}$ of N, $40 \mathrm{~kg} \mathrm{ha}^{-1}$ of $\mathrm{P}_{2} \mathrm{O}_{5}$ and $60 \mathrm{~kg} \mathrm{ha}^{-1}$ of $\mathrm{K}_{2} \mathrm{O}$ ). Weeds were removed weekly, using a hoe. Before the planting and harvest periods, soil samples were collected $(0-20 \mathrm{~cm})$ in each row with the treatments or the control. Then, they were sent to the laboratory, to determine chemical parameters.

The experimental design was randomized blocks, with four replicates and four treatments (control, 5, 10 and $15 \%$ of $\mathrm{CaO}$ ). Each unit consisted of furrows with $18 \mathrm{~m}$ long $\mathrm{x} 0.6 \mathrm{~m}$ wide each, spaced $0.3 \mathrm{~m}$ between plants and $1.0 \mathrm{~m}$ between furrows. The particle film applications were performed every ten days, starting at 30 DAP up to harvest. A semianalytical scale (UX-620H Shimadzu) was used to

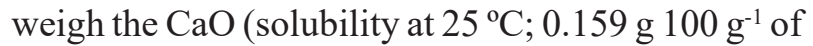
the solution - $1.2 \mathrm{~g} \mathrm{~L}^{-1}$ ), and distilled water was added to obtain the desired concentrations. The films were applied using a costal electric sprayer (Kawashima PEM-P20) with a flow rate of $2.9 \mathrm{~L} \mathrm{~min}^{-1}$ and pressure of $450 \mathrm{kPa}$. A total volume of $83.5 \mathrm{~mL}$ was sprayed on the leaves according to the $\mathrm{CaO}$ concentrations. One plant per unit was collected every 15 days, after each application, to evaluate its growth and partitioning. Border plants were disregarded to perform these evaluations.

Fresh plants were collected, identified, measured and weighed. An integrator (Li-Cor model LI 3000) was used to measure the leaf area. After that, they were put into paper bags and placed in a forced-air circulation oven at $65{ }^{\circ} \mathrm{C}$, for 72 hours. Finally, the dry mass was determined (g). According to Benincasa (2003), when the dry matter mass and the leaf area are obtained at regular pre-established intervals, the following parameters can be determined: absolute

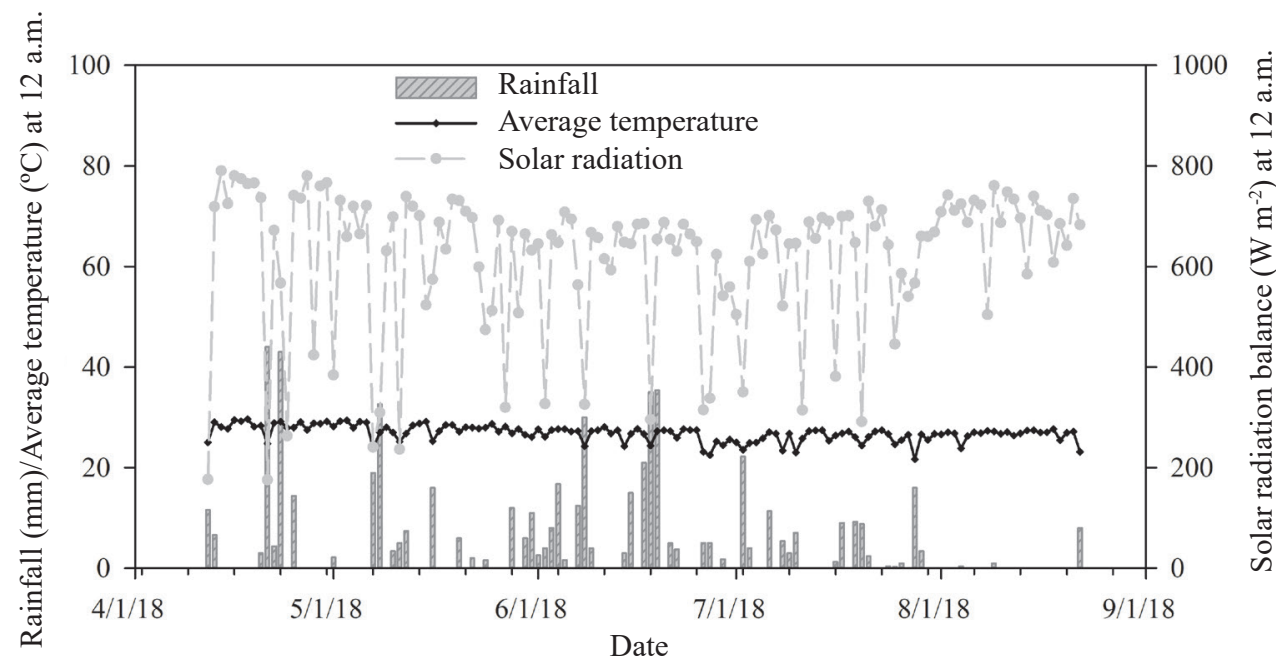

Figure 1. Average air temperature $\left({ }^{\circ} \mathrm{C}\right)$, accumulated solar radiation $(\mathrm{Rn})\left(\mathrm{W} \mathrm{m}^{-2}\right)$ and daily cumulative rainfall $(\mathrm{mm})$, from April to September 2018. 
growth rate $\left(\mathrm{g} \mathrm{day}^{-1}\right.$; variation or increase between two samples that indicate the plant growth rate); relative growth rate $\left(\mathrm{g} \mathrm{g}^{-1}\right.$ day $^{-1}$; increase in dry matter mass per unit of initial weight in a determined time interval); net assimilation rate $\left(\mathrm{g} \mathrm{m}^{-2}\right.$ day $^{-1}$; increase in dry matter mass accumulated in the plant per unit of leaf area available during a time range); leaf mass ratio $\left(\mathrm{cm}^{2} \mathrm{~cm}^{-2}\right.$; balance between the leaf area and the area occupied by the plants); leaf area ratio $\left(\mathrm{cm}^{2} \mathrm{~g}^{-1}\right.$; ratio between the leaf area and the dry plant mass); leaf area index ( $\mathrm{g} \mathrm{g}^{-1}$; ratio of the leaf dry weight to the total dry mass); crop growth rate ( $\mathrm{g} \mathrm{m}^{-2}$ day $^{-1}$; total amount of dry matter accumulated per unit area of soil in a determined time); and crop index (quotient often used to measure the conversion efficiency of synthesized products into the material of economic importance) (Marafon 2012).

The yield was obtained by the root weight from each plot. The total weight was extrapolated to $t \mathrm{ha}^{-1}$. The mean root diameter was obtained by the transversal measurement of the central part of the root, using a digital caliper, and expressed in $\mathrm{mm}$. The displacement of water volume allowed to obtain the root volume by the graduated cylinder $(\mathrm{mL})$ (Torres Netto et al. 2006).

The starch content was determined by the Lane-Eynon method. This method reduces a defined volume of an alkaline copper reagent (Fehling) to cuprous oxide. The endpoint is indicated by methylene blue and facilitated by a slight excess of reducing sugar (Zenebon et al. 2008).

The data were submitted to Anova $(\alpha=0.05)$ and regression analysis. All analyses were performed using the R software (Bhering 2017) and graphs designed using the SigmaPlot 12.5 software.

\section{RESULTS AND DISCUSSION}

According to the soil analysis, the $\mathrm{pH}$ was higher in the experimental plots where $\mathrm{CaO}$ films were applied, as well as $\mathrm{Ca}+\mathrm{Mg}$ and $\mathrm{Ca}$ (Table 1), indicating that the particle film may cause a local indirect liming in the soil, increasing its $\mathrm{pH}$ and, therefore, the plant nutrient absorption.

The particle film caused artificial shading, and the application occurred on leaves. In case of rain (what happened in the experimental period), the leaves ended up being washed, and the Ca flowed into the soil. Thus, by applying the calcium-based particle film $(\mathrm{CaO})$, it was possible to provide the soil with a higher $\mathrm{Ca}^{2+}$ content, consequently raising the $\mathrm{pH}$, what caused an increase in the microbial activity and the release of nutrients from the soil (Silva et al. 2011).

The number of commercial roots (Figure 2A) and yield (Figure 2C) tended to increase as the $\mathrm{CaO}$ particle film also increased, while the percentage of commercial roots increased in $\mathrm{CaO}$ concentrations up to $10 \%$, decreasing thereafter (Figure $2 \mathrm{~B}$ ).

The root volume (Figure 3A), diameter (Figure 3B) and weight (Figure 3C) showed a linear relation between days after planting and calcium particle films concentrations. Plants treated with $\mathrm{CaO}$ at 10 and $15 \%$ showed the highest root volume and weight values, being roughly similar for diameter (Figure 3).

At $10 \%$ of $\mathrm{CaO}$, a more significant sweet potato production potential was noted. It possibly occurred due to the particle film effect as a barrier to UV excess and IR radiation, causing a reduction in the luminous stress, allowing the active photosynthetically leaf area to absorb solar energy and dry mass conversion (Glenn 2012, Slattery et al. 2017).

The highest starch content values were observed at 120 DAP (Figure 4). The starch content was higher for the control, mostly at 120 and 135 DAP, for all treatments.

The beginning of root starch accumulation is a significant development stage of the sweet potato, as it marks the photoassimilates translocation to this reserve, modifying the source/drain ratio of the plant (Schons et al. 2007). In this study, the starch ended up being remobilized for the root growth in its final

Table 1. Soil chemical analysis after the particle film application.

\begin{tabular}{|c|c|c|c|c|c|c|}
\hline Sample & $\mathrm{pH}$ & $\begin{array}{c}\mathrm{OM} \\
\%\end{array}$ & $\mathrm{Ca}+\mathrm{Mg}$ & $\mathrm{Ca}$ & $\mathrm{Mg}$ & $\mathrm{Al}$ \\
\hline Control & 5.52 & 1.49 & 2.00 & 1.33 & 0.67 & 0.0 \\
\hline $5 \%$ of $\mathrm{CaO}$ & 6.59 & 1.39 & 2.39 & 1.82 & 0.57 & 0.0 \\
\hline $10 \%$ of $\mathrm{CaO}$ & 6.94 & 1.51 & 3.68 & 2.67 & 1.01 & 0.0 \\
\hline $15 \%$ of $\mathrm{CaO}$ & 7.66 & 1.47 & 4.12 & 3.39 & 0.73 & 0.0 \\
\hline
\end{tabular}


phase (120-135 DAP), as can be seen with the higher starch content in the control group, when compared to particle film treatments. At harvest (150 DAP), the particle film, mainly at 5 and $10 \%$ of $\mathrm{CaO}$, showed the highest starch content, when compared to the other treatments. The fact that there is a decrease in the starch content at harvest suggests that, instead of producing starch, the plant demanded root growth, filling and weight (Figure 2).
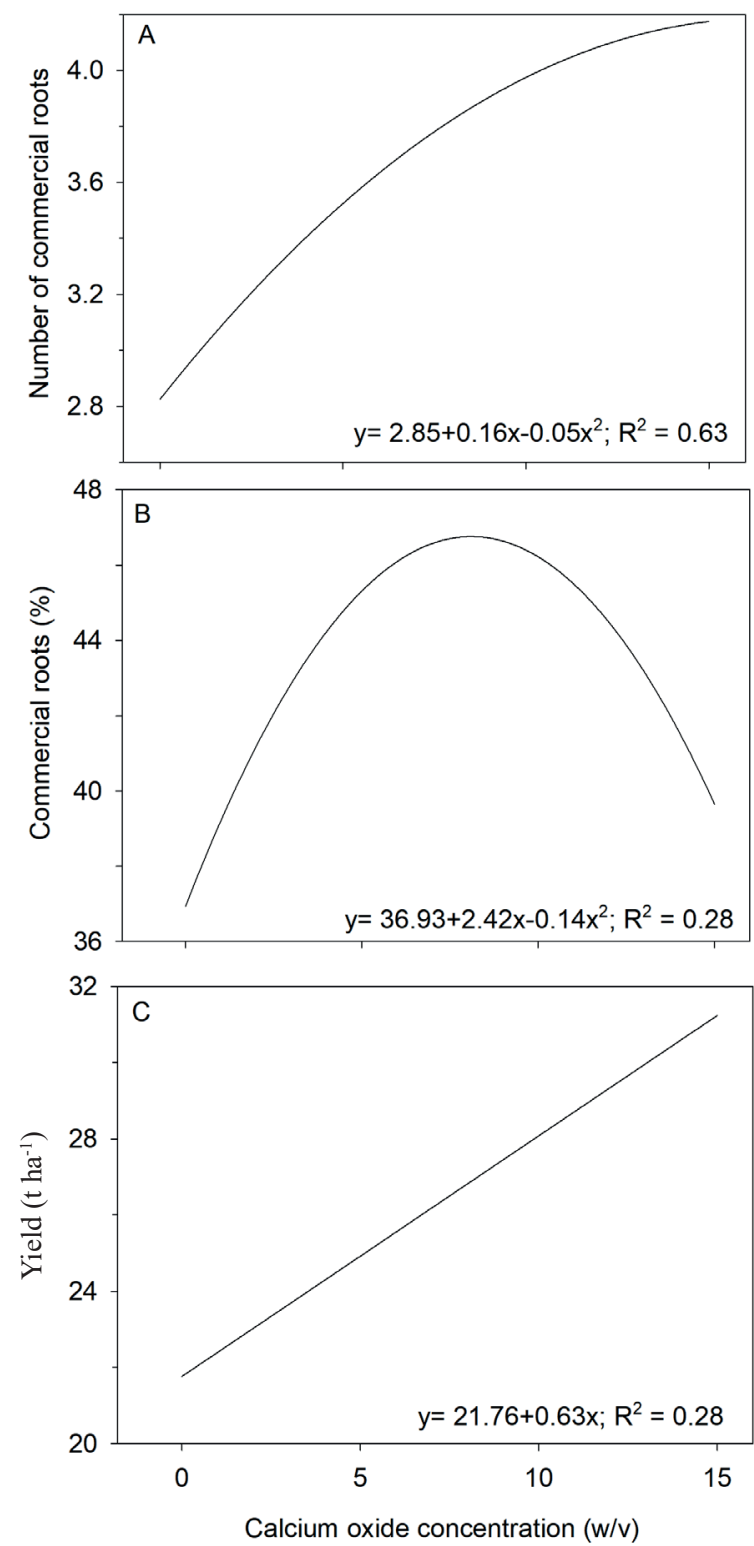

Figure 2. Number (A) and percentage (B) of commercial roots and estimated yield $\left(\mathrm{t} \mathrm{ha}^{-1}\right)(\mathrm{C})$ of sweet potato (Ipomoea batatas L.), according to the application of three concentrations $(5,10$ and $15 \%)$ of calcium oxide particle film. The control ( 0 ) consisted of water application.
The fresh (Figure 5A) and dry (Figure 5D) root matter showed a linear relationship that increased the DAP, mostly at 10 and $15 \%$ of $\mathrm{CaO}$. A nonlinear association was observed for branches, where the fresh (Figure 5B) and dry (Figure 5E) matter increased up to 105 DAP, and after decreased chiefly in the control, 5 and $15 \%$ of $\mathrm{CaO}$. A non-linear relationship was found for leaf fresh (Figure 5C) and dry (Figure 5F) matter and, overall, it increased up
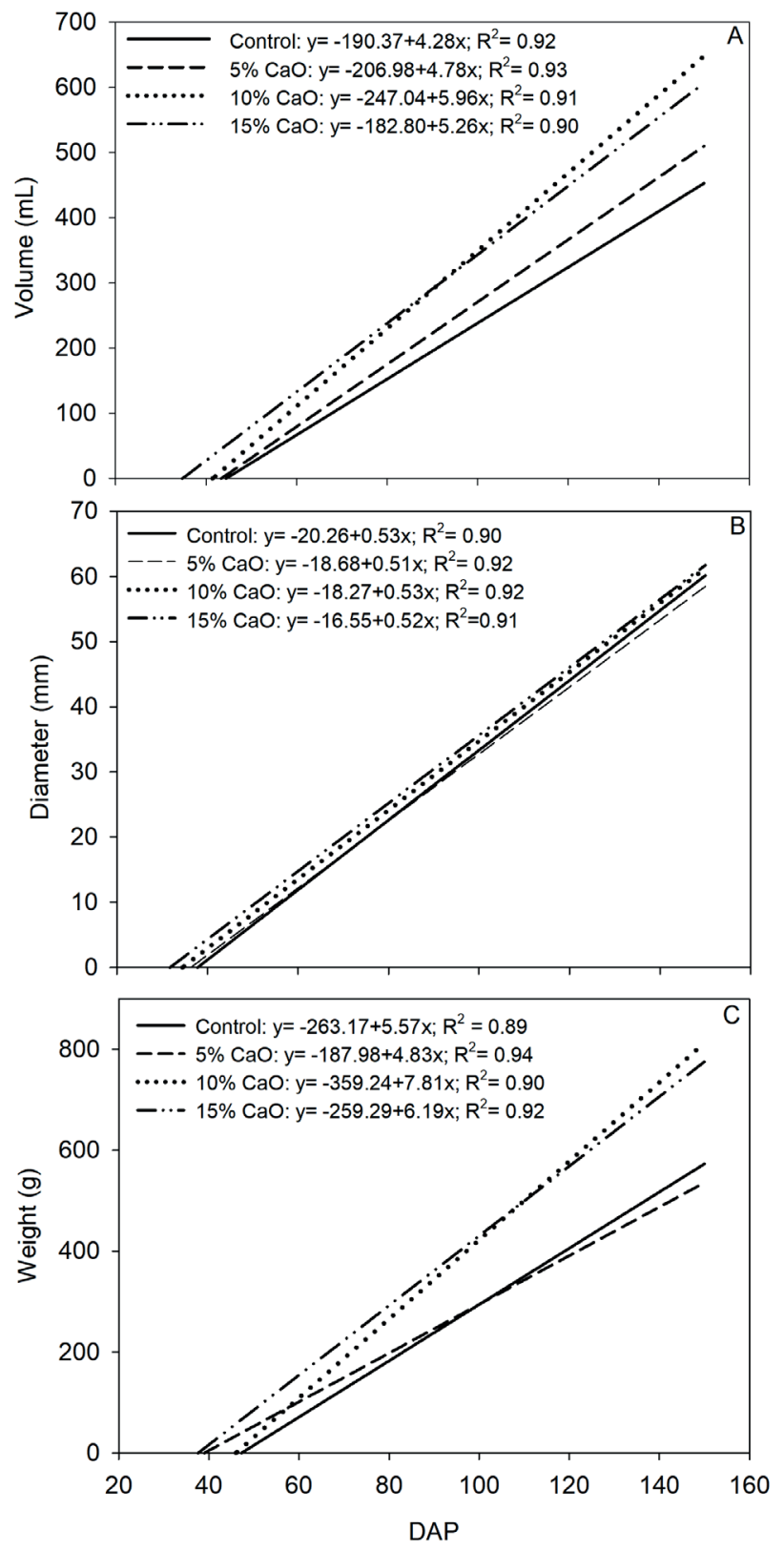

Figure 3. Root volume (A), diameter (B) and average weight per $\operatorname{root}(\mathrm{C})$ of sweet potato (Ipomoea batatas $\mathrm{L}$.) submitted to concentrations of calcium-based particle film. DAP: days after planting. 


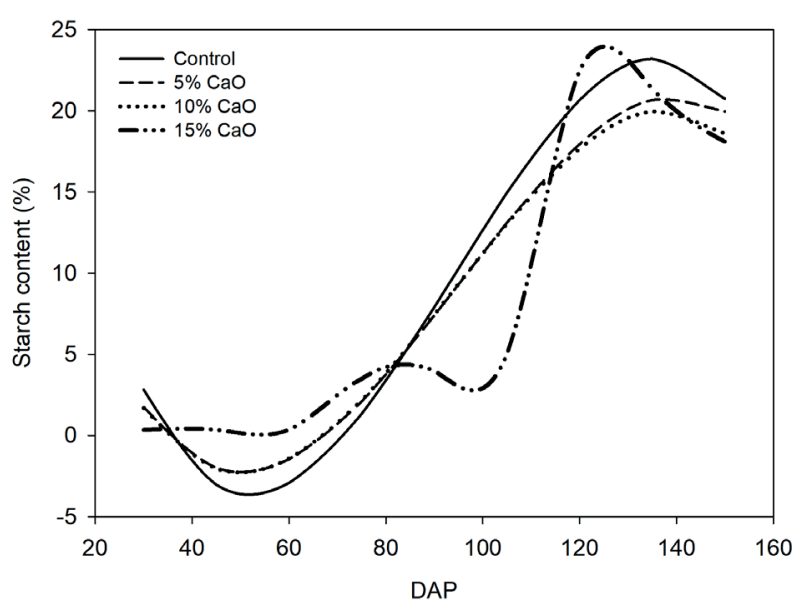

Figure 4. Starch content for sweet potato (Ipomoea batatas L.) submitted to particle film concentrations: control $(\mathrm{y}=$ $\left.39.68-1.91 \mathrm{x}+0.02 \mathrm{x}^{2}-0.01 \mathrm{x}^{3} ; \mathrm{R}^{2}=0.76\right) ; 5 \%$ of $\mathrm{CaO}$ $\left(\mathrm{y}=27.24-1.33 \mathrm{x}+0.01 \mathrm{x}^{2}-0.01 \mathrm{x}^{3} ; \mathrm{R}^{2}=0.80\right) ; 10 \%$ of $\mathrm{CaO}\left(\mathrm{y}=27.43-1.35 \mathrm{x}+0.02 \mathrm{x}^{2}-0.01 \mathrm{x}^{3} ; \mathrm{R}^{2}=0.79\right)$; and $15 \%$ of $\mathrm{CaO}\left(\mathrm{y}=0.34+0.83 \mathrm{x}+0.04 \mathrm{x}^{2}-0.01 \mathrm{x}^{3}\right.$; $\left.\left.\mathrm{R}^{2}=0.93\right)\right]$. DAP: days after planting.

to $105 \mathrm{DAP}$, and then decreased. An exception was observed at $15 \%$ of $\mathrm{CaO}$, peaking at $75 \mathrm{DAP}$ and showing a slight reduction, when compared to the other treatments.

This biomass allocation between roots and leaves generates a balance in the plant growth, adaptation to environmental changes and possible stresses (water and light). Plants allocate more biomass in the stems/branches to facilitate the competition for light and carbon acquisition. Thus, a plant can distribute more biomass to the roots, allowing a higher nutrient absorption and biomass increase. Conversely, a plant can regulate its root morphology and physiology, instead of allocating more biomass to its roots, when there are abundant soil water and nutrients ( $\mathrm{Li}$ et al. 2014).

The absolute growth rate showed a continuous trend for all treatments and, at $10 \%$ of $\mathrm{CaO}$, it reached $40 \mathrm{~g} \mathrm{day}^{-1}$ at $150 \mathrm{DAP}$ (Figure 6A). The relative growth rate reduced as the sweet potato developed (Figure 6B), and the net assimilation rate values varied (Figure 6C). For the control and $10 \%$ of $\mathrm{CaO}$, there was an increase in the middle of the sweet potato development and, in the end, it showed a sharp decrease (Figure 6C). However, at 5 and $15 \%$ of $\mathrm{CaO}$, the opposite was observed.

The leaf mass ratio also presented trends according to the $\mathrm{CaO}$ concentrations (Figure 6D). There was an increase during the plant development at 10 and $15 \%$ of $\mathrm{CaO}$, while, for $5 \%$ of $\mathrm{CaO}$ and control, the leaf mass ratio remained similar. The leaf area ratio (Figure 6E) presented a continuous growth with a high increase in crop harvest at 10 and $15 \%$ of $\mathrm{CaO}$. The control and $5 \%$ of $\mathrm{CaO}$ tended to increase at $120 \mathrm{DAP}$, followed by a reduction, while $5 \%$ had high values.

The leaf area index values were higher at $120 \mathrm{DAP}$ at $5 \%$ and $15 \%$ of $\mathrm{CaO}$ and control, respectively, while, for $10 \%, 150$ DAP were observed (Figure 6F). The crop growth rate values were higher for $5 \%$ of $\mathrm{CaO}$ and control at $120 \mathrm{DAP}$, respectively (Figure 6G). At 10\%, the peak occurred at $90 \mathrm{DAP}$ and, at $15 \%$, it varied during the crop development, with an increase at 45 DAP. Finally, the crop index increased for the control and $10 \%$ of $\mathrm{CaO}$ (Figure $6 \mathrm{H}$ ). The concentrations of 5 and $15 \%$ of $\mathrm{CaO}$ increased gradually up to $135 \mathrm{DAP}$, without variation at 150 DAP.

Based on the decrease in the leaf fresh and dry mass (with an increase in the roots at 90 DAP), an inverse relationship was verified as photoassimilates translocated to the roots. Such behavior is corroborated by the initial crop establishment curves (Figure 4) that coincide with root growth, with a subsequent reduction in development, up to the maturation and filling of the tuberous roots and senescence of the leaves (Câmara et al. 2017).

As the effect of particle film application, the decrease in the relative growth rate may be explained by an increase in the respiratory activity, the promoted artificial shading and improvements in non-assimilating tissues (Barreiro et al. 2006). Thus, the highest relative growth at $10 \%$ of $\mathrm{CaO}$ may be explained by the initial investment in leaf area formation and its photosynthetic capacity (Câmara et al. 2017). The net assimilation rate is a physiological indicator strongly related to photosynthetic efficiency, and this index must be evaluated with the leaf area ratio that explained the relative growth rate.

The leaf area ratio indicates the leaf area used to produce $1 \mathrm{~g}$ of dry mass (Benincasa 2003). Thus, it is possible that, in control plots, an increase in the interference of the upper leaves on the lower ones (self-shading) decreased the functional leaf area (Ford 2014, Niinemets 2016). This interference is supported in plots that received 10 and $15 \%$ of $\mathrm{CaO}$, where such a relationship increased in the final stage of the crop cycle, as it is necessary for the growth of tuberous roots that become drains (Singh et al. 1998). 

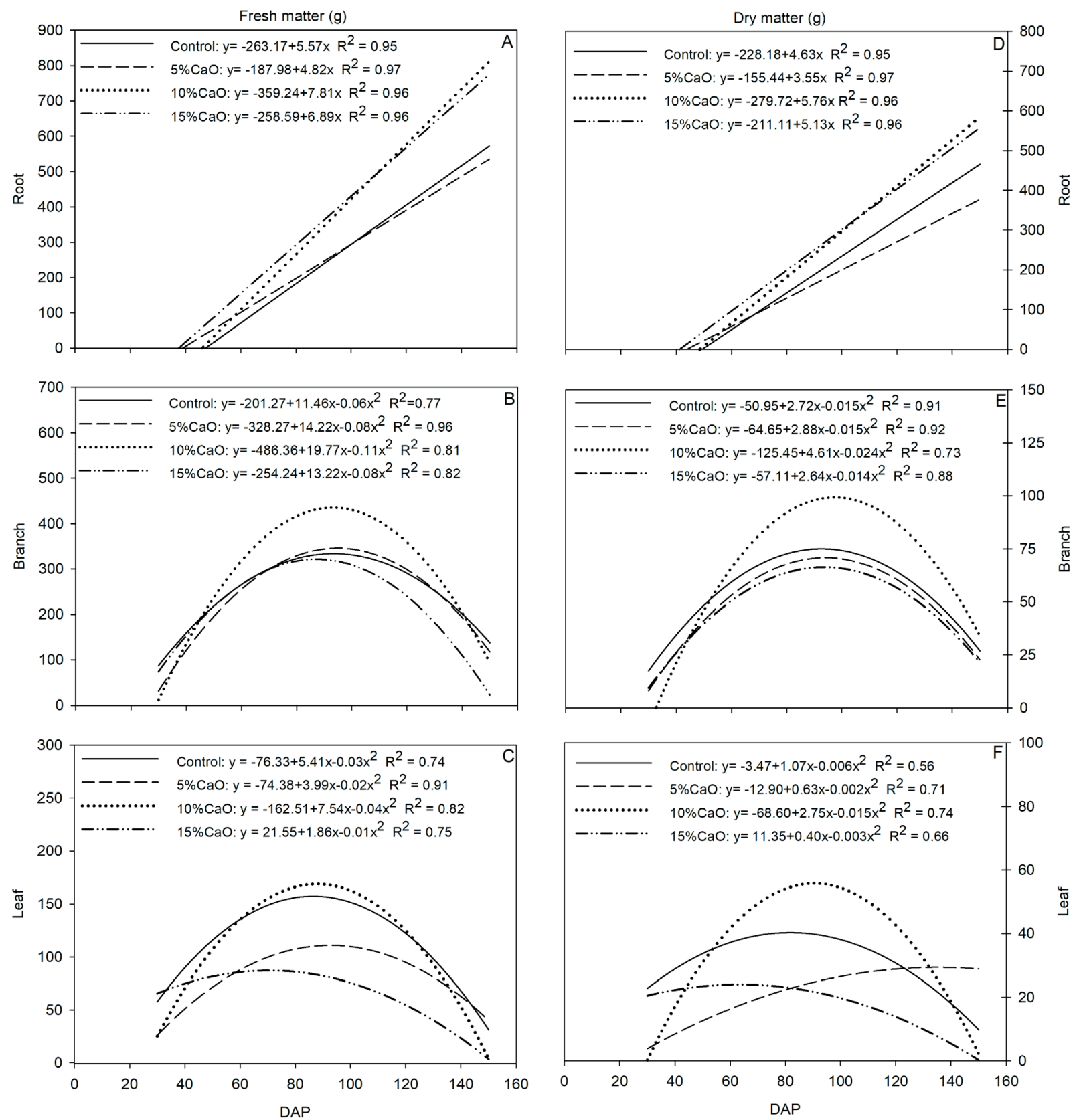

Figure 5. Fresh matter of roots (A), branches (B) and leaves (C), and dry matter of roots (D), branches (E) and leaves (F) of sweet potato (Ipomoea batatas L.), according to the application of calcium oxide particle film $(5,10$ and $15 \%$ of $\mathrm{CaO})$.

The leaf area index describes the size of the photosynthetic device. Thus, the reduction of leaf area index in the control and $5 \%$ of $\mathrm{CaO}$ at the final crop stage may be attributed to senescence and leaf abscission. This reduction is well recognized as a characteristic of sweet potato, due to its habits of determined growth (Conceição et al. 2005). However, at 10 and $15 \%$ of $\mathrm{CaO}$, it changed, and the leaf area index increased to prioritize the partitioning of photoassimilates to roots (Zheng \& Moskal 2009, Portes \& Melo 2014).

Tubers become priority drains in the assimilate partition from the beginning of their development, what indicates that the available photoassimilates were allocated to the root growth (Singh et al. 1998, Fernandes et al. 2010).

Plants with a high leaf area development had a better capacity to intercept solar radiation 

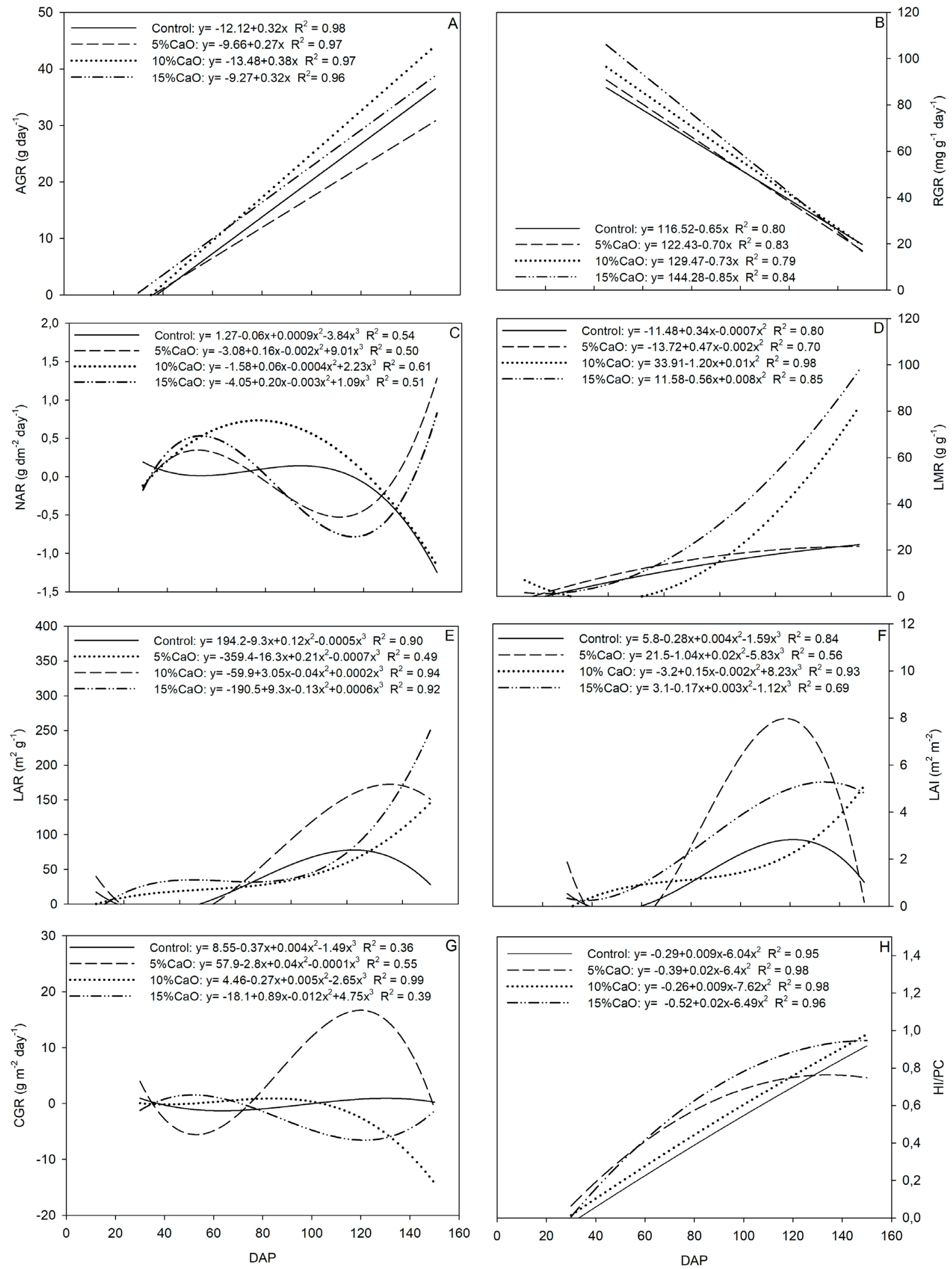

Figure 6. Growth rates of sweet potato (Ipomoea batatas L.) submitted to concentrations of calcium-based particle film (CaO). AGR: absolute growth rate; RGR: relative growth rate; NAR: net assimilation rate; LMR: leaf mass ratio; LAR: leaf area ratio; LAI: leaf area index; CGR: crop growth rate; HI/PC: harvest index or partition coefficient. 
and, consequently, a higher dry mass production. However, the crop yield depends on the partition of assimilates produced in photosynthesis into roots, and the "strength" of roots as drains in the allocation of assimilates is the primary factor in determining the sweet potato yield (Oliveira et al. 2016).

The highest yield occurred at $150 \mathrm{DAP}$, at $10 \%$ $\left(34.98 \mathrm{tha}^{-1}\right)$ and $15 \%\left(30.8 \mathrm{t} \mathrm{ha}^{-1}\right)$ of $\mathrm{CaO}$. Such values are a result of the particle film application on sweet potato partitioning, and, taken together, increased the number of commercial roots, average weight per root and root volume.

\section{CONCLUSIONS}

1. The application of calcium oxide particle films improves the morpho-agronomic aspects, growth and yield of sweet potato, due to the artificial shading provided by them;

2. The concentration of $10 \%$ of $\mathrm{CaO}$ increases the remobilization of photoassimilates and, consequently, the sweet potato yield.

\section{ACKNOWLEDGMENTS}

This study was partially financed by the Conselho Nacional de Desenvolvimento Científico e Tecnológico $(\mathrm{CNPq})$, Fundação de Apoio à Pesquisa e à Inovação Tecnológica do Estado de Sergipe (Fapitec/SE), Coordenação de Aperfeiçoamento de Pessoal de Nível Superior (Capes - Finance Code 001) and Financiadora de Estudos e Projetos (Finep).

\section{REFERENCES}

ALLEN, R. G.; PEREIRA, L. S.; RAES, D.; SMITH, M. Crop evapotranspiration: guidelines for computing crop water requirements. Rome: FAO, 1998.

BARREIRO, A. P.; ZUCARELI, V.; ONO, E. O.; RODRIGUES, J. D. Análise de crescimento de plantas de manjericão tratadas com reguladores vegetais. Bragantia, v. 65 , n. 4 , p. 563-567, 2006.

BENINCASA, M. M. P. Análise de crescimento de plantas: noções básicas. Jaboticabal: Funep, 2003.

BHERING, L. L. Rbio: a tool for biometric and statistical analysis using the R platform. Crop Breeding and Applied Biotechnology, v. 17, n. 2, p. 187-190, 2017.

BRITO, C.; DINIS, L. T.; FERREIRA, H.; ROCHA, L.; PAVIA, I.; MOUTINHO-PEREIRA, J.; CORREIA,
C. M. Kaolin particle film modulates morphological, physiological and biochemical olive tree responses to drought and rewatering. Plant Physiology and Biochemistry, v. 133, n. 1, p. 29-39, 2018.

CÂMARA, F. A. A.; GRANGEIRO, L. C.; DOMBROSKI, J. L. D.; FREITAS, R. M. O.; FREITAS, F. C. L.; NEGREIROS, M. Z. Crescimento de cultivares de Ipomoea batatas oriundas de rebentos produzidas de forma convencional e in vitro. Revista Ciência Agronômica, v. 40, n. 2, p. 363-372, 2017.

CHANDRASEKARA, A.; KUMAR, T. J. Roots and tuber crops as functional foods: a review on phytochemical constituents and their potential health benefits. International Journal of Food Science, v. 2016, n. 1, p. 1-15, 2016.

CONCEIÇÃO, M. K.; LOPES, N. F.; FORTES, G. R. L. Análise de crescimento de plantas de batata-doce (Ipomoea batatas (L.) Lam) cultivares abóbora e da costa. Revista Brasileira de Agrociência, v. 11, n. 3, p. 273-278, 2005.

FAHAD, S.; BJAWA, A. A.; NAZIR, U.; ANJUM, S. A.; FAROOQ, A.; ZOHAIB, A.; SADIA, S.; NASIM, W.; ADKINS, S.; SAUD, S.; IHSAN, M. Z.; ALHARBY, H.; WU, C.; WANG, D.; HUANG, J. Crop production under drought and heat stress: plant responses and management options. Frontiers in Plant Science, v. 8, n. 1, p. 1-16, 2017.

FERNANDES, A. M.; SORATTO, R. P.; SILVA, B. L.; SOUZA-SCHLICK, G. D. Crescimento, acúmulo e distribuição de matéria seca em cultivares de batata na safra de inverno. Pesquisa Agropecuária Brasileira, v. 45, n. 8, p. 826-835, 2010.

FIGUEIREDO, J. A.; ANDRADE JÚNIOR, V. C.; PEREIRA, R. C.; RIBEIRO, K. G.; VIANA, D. J. S.; NEIVA, I. P. Avaliação de silagens de ramas de batatadoce. Horticultura Brasileira, v. 30, n. 4, p. 708-712, 2012.

FOOD AND AGRICULTURE ORGANIZATION (FAO). Faostat-crops. 2019. Available at: http://www.fao.org/ faostat/en/\#data/QC. Access on: 25 June 2020.

FORD, E. D. The dynamic relationship between plant architecture and competition. Frontiers in Plant Science, v. 5, n. 1, p. 1-13, 2014.

GIFFORD, R. M.; THORNE, J. H.; HITZ, W. D.; GIAQUINTA, R. T. Crop productivity and photoassimilate partitioning. Science, v. 225, n. 4664, p. 801-808, 1984.

GLENN, D. M. The mechanisms of plant stress mitigation by kaolin-based particle films and applications in horticultural and agricultural crops. HortScience, v. 47, n. 6 , p. 710-711, 2012.

INSTITUTO BRASILEIRO DE GEOGRAFIA E ESTATÍSTICA(IBGE). Produto das lavouras temporárias 
e permanentes. 2017. Available at: https://sidra.ibge.gov. br/tabela/5457\#resultado. Access on: 26 June 2020.

LI, Z.; ZHANG, Y.; YU, D.; ZHANG, N.; LIN, J.; ZHANG, J.; TANG, J.; WANG, J.; UM, C. The influence of precipitation regimes and elevated $\mathrm{CO}_{2}$ on photosynthesis and biomass accumulation and partitioning in seedlings of the rhizomatous perennial grass Leymus chinensis. Plos One, v. 9, n. 8, p. 1-9, 2014.

MARAFON, A. C. Análise quantitativa de crescimento em cana-de-açúcar: uma introdução ao procedimento prático. Aracaju: Embrapa Tabuleiros Costeiros, 2012.

NIINEMETS, Ü. Leaf age dependent changes in withincanopy variation in leaf functional traits: a meta-analysis. Journal of Plant Research, v. 129, n. 3, p. 313-338, 2016.

OLIVEIRA, J. S.; BROWN, H. E.; GASH, A.; MOOT, D. J. An explanation of yield differences in three potato cultivars. Agronomy Journal, v. 108, n. 4, p. 1434-1446, 2016.

PEIXOTO, C. P.; CRUZ, T. V.; PEIXOTO, M. F. S. P. Análise quantitativa do crescimento de plantas: conceitos e prática. Enciclopédia Biosfera, v. 7, n. 13, p. 51-76, 2011.

PORTES, T. A.; MELO, H. C. Light interception, leaf area and biomass production as a function of the density of maize plants analyzed using mathematical models. Acta Scientiarum Agronomy, v. 36, n. 4, p. 457-463, 2014.

RAYMUNDO, R.; ASSENG, S.; CAMMARANO, D.; QUIROZ, R. Potato, sweet potato, and yam models for climate change: a review. Field Crops Research, v. 166, n. 1, p. 173-185, 2014.

SANTOS, V. P.; FERNANDES, P. D.; MELO, A. S.; SOBRAL, L. F.; BRITO, M. E. B.; DANTAS, J. D. M.; BONFIM, L. V. Fertirrigação da bananeira cv. Prata-Anã com N e K em um Argissolo Vermelho-Amarelo. Revista Brasileira de Fruticultura, v. 31, n. 2, p. 567-573, 2009.

SCHONS, A.; STRECK, N. A.; KRAUliCH, B.; PINHEIRO, D. G.; ZANON, A. J. Emissão de folhas e início de acumulação de amido em raízes de uma variedade de mandioca em função da época de plantio. Ciência Rural, v. 37 , n. 6 , p. 1586-1592, 2007.
SILVA, I. P. F.; SILVA JUNIOR, J. F.; ARALDI, R.; TANAKA, A. A.; GIROTTO, M.; BOSQUE, G. G.; LIMA, F. C. C. Preparo de solo e calagem na cultura da batata. Revista Cientifica Eletrônica de Agronomia, v. 20, n. 1, p. 1-15, 2011.

SILVA, P. S. O.; OLIVEIRA, L. F. G.; GONZAGA, M. I. S.; SENA, E. O. A.; MACIEL, L. B. S.; FIAES, M. P.; MATTOS, E. C.; CARnelossi, M. A. G. Effects of calcium particle films and natural shading on ecophysiological parameters of conilon coffee. Scientia Horticulturae, v. 245, n. 1, p. 171-177, 2019a.

SILVA, P. S. O.; SENA, E. O. A.; GONZAGA, M. I. S.; OLIVEIRA, L. F. G.; MACIEL, L. B. S.; SANTOS, M. P. F.; MATTOS, E. C.; DIAS, K. L. L.; CARNEIRO, R. B.; CARNELOSSI, M. A. G. Calcium carbonate particle films and water regimes affect the acclimatization, ecophysiology and reproduction of tomato. Environmental and Experimental Botany, v. 165, n. 1, p. 19-29, 2019 b.

SINGH, U.; MATTHEWS, R. B.; GRIFFIN, T. S.; RITCHIE, J. T.; HUNT, L. A.; GOENAGA, R. Modeling growth and development of root and tuber crops. In: TSUJI, G. Y.; HOOGENBOOM, G.; THRORNTON, P. K. (org.). Understanding options for agricultural production. 7 ed. Dordrecht: Springer, 1998. p. 129-156.

SLATTERY, R. A.; VANLOOCKE, A.; BERNACCHI, C. J.; ZHU, X. G.; ORT, D. R. Photosynthesis, light use efficiency, and yield of reduced-chlorophyll soybean mutants in field conditions. Frontiers in Plant Science, v. 8, n. 1, p. 1-19, 2017.

TORRES NETTO, A.; CAMPOSTRINI, E.; GOMES, M. M. A. Effects of root confinement on byometrics measurements and $\mathrm{CO}_{2}$ assimilation in Coffea canephora pierre plants. Revista Brasileira de Agrociência, v. 12, n. 3, p. 295-303, 2006.

ZENEBON, O.; PASCUET, N. S.; TIGLEA, P. Métodos físico-químicos para análise de alimentos. São Paulo: Instituto Adolfo Lutz, 2008.

ZHENG, G.; MOSKAL, L. M. Retrieving leaf area index (LAI) using remote sensing: theories, methods and sensors. Sensors, v. 9, n. 4, p. 2719-2745, 2009. 